\title{
THE ROLE AND IMPORTANCE OF ECB'S MONETARY POLICY IN THE GLOBAL ECONOMIC CRISIS ${ }^{* *}$
}

This paper presents the role and importance of the European Central Bank (ECB) in the context of measures and effects that are being taken to repair the consequences of the current economic crisis. The ECB, together with the European single currency, the euro, symbolizes long-lasting monetary integration of the EU states. Such form of integration has created the possibility of a supranational action of ECB in the banking sector and financial markets in general. Along with the other most important central banks in the world, the ECB applies various unconventional instruments of monetary policy to stimulate economic growth and development. In this context, the paper explains the nature and mechanism of such measures in order to influence on the insufficient liquidity in the financial markets.

Key words: ECB, monetary policy, non-standard measures, financial markets

\section{Introduction}

After the first indications of the global financial crisis in 2007 and its intensification one year later (the bankruptcy of one of the largest investment banks - Lehman Brothers), new circumstances were generated, which called for the implementation of non-standard and unconventional measures of monetary policy by the most significant central banks in the world. Addressing the issue of insufficient international liquidity and boosting the weak aggregate demand implied the establishment of new mechanisms that would be at the central banks' disposal within the scope of their instruments. After September 2008, in the aftermath of the mentioned bankruptcy, the financial market, in particular money markets have been hit by a considerable increase in insecurity and panic. Interest rate spreads at the European, US an UK markets reached the unprecedented levels, whereas, on the other hand, the volume of transactions drastically

Nikola Stakić, MSc, Faculty of Business Studies, Megatrend University, Belgrade, e-mail: nstakic@megatrend.edu.rs

** Paper presented at the $10^{\text {th }}$ N.E.W.S. Conference - Global University Network, held by Megatrend University from $10^{\text {th }}$ to $14^{\text {th }}$ September 2013 in Belgrade. 
fell (especially when it comes to forward transactions). Effectiveness of transmission mechanism of monetary policy was brought into question given that the financial market players ended up in the position of a "liquidity trap".

Such circumstances called for a swift and decisive reaction of monetary authorities. In addition to carrying out expansionary monetary policy by means of traditional instruments (including, for instance, reduction of reference interest rates), the central banks presented a set of the so-called non-standard measures in order to adequately adjust to the current developments. The mechanism and forms of these measures somewhat differ among the central banks involved, but, despite this, they all strive towards the same objectives - support to the financial markets and prevention of the financial systems' disruption, which would in the mid term threaten the macroeconomic and price-related stability. The differences in the "design" of the central banks' measures which are being topical from the late 2008 depended on several factors: structure itself of the present standard monetary policy measures, balance sheet size of the concerned central banks, and structure of the financial systems of the region in which a certain country was located.

The separateness of standard and non-standard measures of monetary policy has been explicitly demonstrated through their effects on the financial markets, especially if one follows in parallel the development before and during the global financial and economic crisis. The mechanism of standard measures of open market operations is rather familiar and many scientific reference books analyze their impact on real economy and the price level. When it comes to nonstandard measures, however, the situation is somewhat different. By their nature, they are located outside the regular scope of monetary actions and, as such, impose the need for their further analyses and required scientific justifiability. Many non-standard measures implemented from 2007 represent a modification of the existing instruments and procedures used in monetary policy. These modifications implied the changes in the role of the central banks themselves: ranging from mediators at the interbank money market through holders and portfolio managers to lenders of the last resort.

The existence of a single currency in a multi-country area can be seen to create disincentives for individual governments to properly tackle fiscal and structural policies as well as to safeguard financial stability. The crisis has shown that the original institutional set-up of EMU only partially corrected for such disincentives. Excessive debt and leverage had built up prior to the crisis, in private and public, financial and non-financial sectors, with imbalances emerging across the euro zone and elsewhere. The paper reviews the ECB's specific nonstandard monetary policy responses in the three main phases of the crisis, which mutated from a global financial crisis to a sovereign debt crisis in the euro zone and was later intertwined with renewed strain in the banking system in parts of the euro zone, with significant fragmentation across countries. 


\section{Quantitative easing}

The most widespread and most frequently used non-standard measure of monetary policy is so-called quantitative easing. In situations when traditional instruments no longer have impact on macroeconomic aggregates because the reference interest rate reached its lowest possible level, and at the same time there is no other economic stimulus, central banks undertake a different set of measures. Namely, they purchase various forms of financial assets from commercial banks and other (non)financial institutions, thus generating additional money supply in order to inject "fresh" capital into the financial flows. This measure differs from the typical buying or selling of government securities with a view to impacting the reference interest rate. Quantitative easing increases the surplus of banks' reserves and causes an increase in financial assets prices, at the time reducing their returns.

As opposed to open market operations where the focus is on short-term government securities, when implementing quantitative easing central bank purchase long-term government bonds in order to impact additional reduction of long-term interest rates on the revenue curve (in the mentioned situations when short-term interest rates are close to zero or zero, the classic monetary policy can no longer reduce them in the long run). How does the process of quantitative easing implementation actually work?

Direct injection of capital into the financial system by the central bank, through purchasing mostly government securities, may have various effects (Diagram 1). The sellers of financial assets acquire a surplus of cash which, they may spend, thus triggering further economic activity. Alternatively, they may purchase other financial assets, such as shares or corporate securities. This results in a growth of prices of financial instruments, increasing the wealth of their owners. Ownership may be direct or indirect, through a share in certain intermediary financial institutions, such as, for instance, private pension and investment funds. Growth of financial instruments' prices also implies lower revenues, which in turn leads to the lower borrowing costs for the corporate and retail sectors. This additionally boosts the consumptions. On the other hand, the banks are in the position to hold a surplus of reverses, which to a large extent they can extend to their clients, thus enhancing their lending activity. However, the question is whether commercial banks would react adequately or whether they would be unwilling to extend loans, thus keeping the surplus of money as part of their reserves. This is exactly why central banks may conduct the process of quantitative easing with other financial institutions as well, which would then involve the purchase of various corporate securities. 
Figure 1: Quantitative easing implementation process

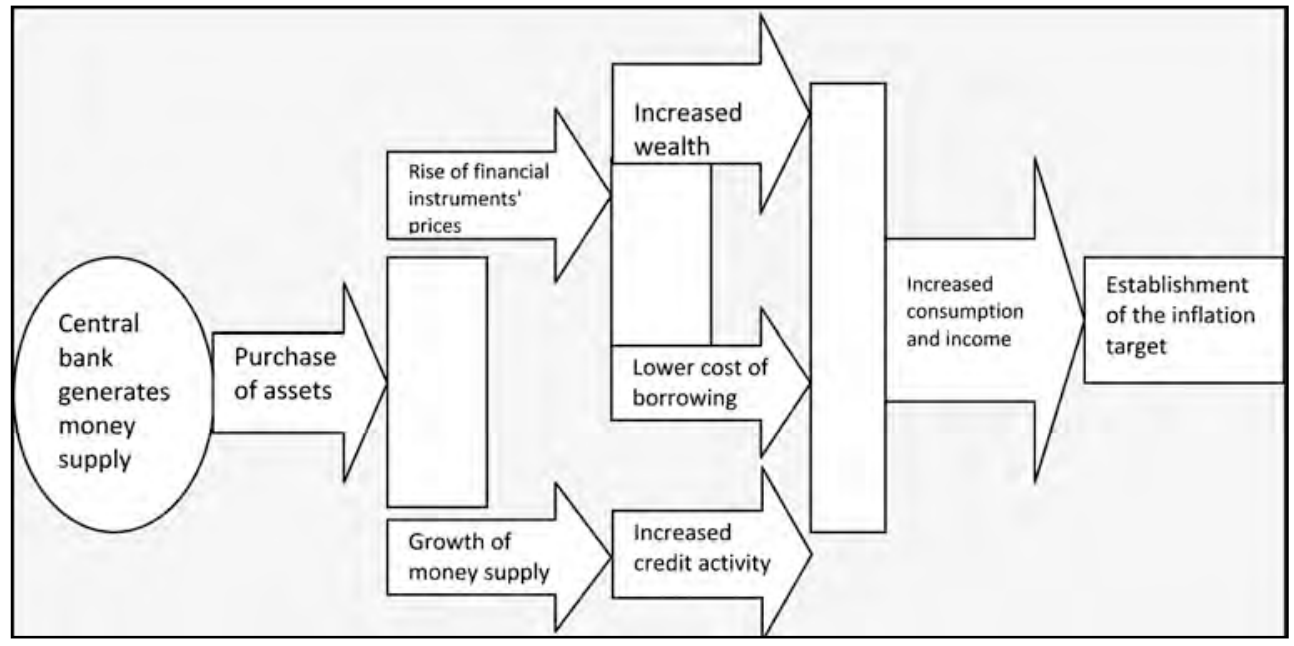

Source: Author

\section{Financial structure of the euro zone}

The euro zone's financial structure differs from that of other large economies. Financial intermediaries - in particular banks - are the main agents for channeling funds from savers to borrowers (ECB, 2007). Banks are the primary source of financing for the economy, most obviously in the case of households. As for firms, more than $70 \%$ of the external financing of the non-financial corporate sector - that is, the financing other than by retained earnings - is provided by banks, and less than $30 \%$ by financial markets (and other funding). In the United States it is the other way around (Figure 1). After the collapse of Lehman Brothers, bank funding started contracting (i.e. a net redemption) at a rate of $€ 100$ billion a year, in sharp contrast to its prior net expansion at a rate which could go up to $€ 600$ billion in 2007. Part of the decline in bank funding was offset by a rise in market funding: debt securities issued by corporations (but also quoted shares issued) increased by more than $€ 100$ billion a year in net terms ${ }^{1}$.

$1 \quad$ Cour-Thimann, P; Winkler, B; The ECB's non-standard monetary policy measures, ECB Working Paper No. 1528, April 2013, 7. 
Figure 2: Funding of the non-financial corporations in the Euro zone and USA

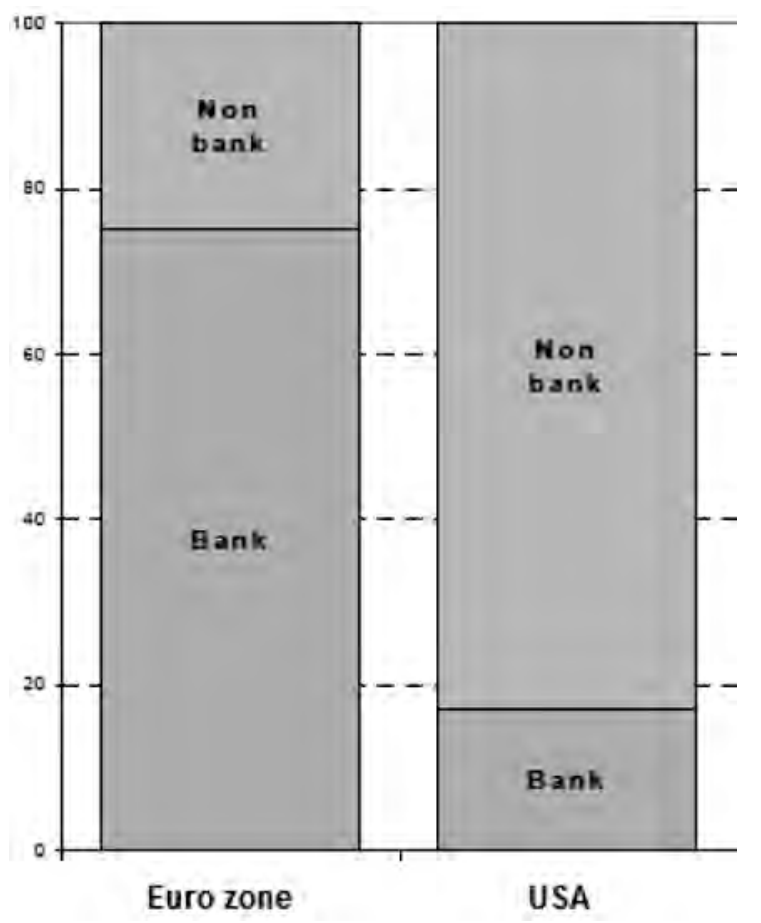

Source: Eurostat, ECB and FED

Banks still play a crucial role in the transmission of policy interest rate decisions to the euro zone economy. In this respect, the ECB's non-standard response to the crisis has accordingly been primarily focused on banks. The operations mainly consist of refinancing operations, to which a large number of counterparties are granted access so as to ensure that the single monetary policy reaches the banking system in all the euro zone countries. This is again different from the US setup, where the Federal Reserve Bank of New York implements monetary policy on behalf of the entire Federal Reserve System and the operations consist mainly of outright purchases and sales of assets in the open market, in line with the essentially market-based structure of the economy. The number of counterparties involved is relatively small, even after having risen during the financial crisis.

In Eurosystem refinancing operations, the individual national central banks grant loans at normally uniform conditions across the euro zone to their counterparties against assets pledged as collateral for a limited, pre-specified period. The list of eligible collateral - about 40,000 assets with a combined value of around $€ 14$ trillion or around $150 \%$ of GDP in 2012 - contains a very wide range 
of public and private sector marketable debt securities and also includes some non-marketable assets ${ }^{2}$.

Since they steer the marginal cost of the refinancing of banks, the monetary policy operations are at the beginning of the transmission chain of the policy signal. The monetary policy stance is signaled by three key ECB interest rates: the rates on the main refinancing operations, the marginal lending facility and the deposit facility. Prior to the financial crisis, decisions and expectations regarding the main refinancing rate were smoothly reflected in the money market yield curve, which was the same throughout the euro zone. The interbank market seemed fully integrated. The creation of EMU had thus been an engine of financial integration: the distinction between a domestic transaction and a cross-border transaction within the euro zone had disappeared. This also meant that if bank transactions during the day led to a net payment outflow, the bank would find the offsetting funding in the interbank market at uniform conditions across the euro zone.

\section{The ECB's monetary policy response to the crisis}

This section reviews how the ECB and the Eurosystem responded to the financial crisis. For simplicity, the measures decided by the ECB's Governing Council are described in this paper as 'ECB' measures; they are actually implemented by the Eurosystem as a whole. Beyond the period of financial turmoil that preceded the financial crisis, it is useful for the purpose of the review to distinguish between two phases, marked by the following:

1) The start of the global financial crisis in September 2008 (Lehman collapse);

2) The start of the euro zone sovereign debt crisis in May 2010 (Greek crisis).

\subsection{The global financial crisis and the ECB's response}

The ECB had already been actively amending its monetary policy implementation in the 13 months of financial turmoil preceding the eruption of the global financial crisis in September 2008. Banks had started to have doubts about the financial health of their counterparties in the interbank market. This drove money market rates up and threatened the appropriate transmission of the ECB's interest rate decisions. From the first day of tensions in interbank markets on 9 August 2007, the ECB acted by accommodating the funding needs of banks, which were seeking to build up daily liquidity buffers so as to reduce

Cour-Thimann, P; Winkler, B; The ECB's non-standard monetary policy measures, ECB Working Paper No. 1528, April 2013, 9. 
uncertainty about their liquidity positions. In particular, the ECB de facto provided unlimited overnight liquidity to banks, allocating $€ 95$ billion on the first day. Later on, the ECB conducted supplementary refinancing operations with maturities of up to 6 months, compared with a maximum of 3 months in normal times ${ }^{3}$. To reduce bank liquidity uncertainty over the turn of the year, all bids above the previous operation's marginal rate were allotted in full in the last main refinancing operation of the year. Temporary swap lines were established with other central banks, primarily to address the mounting pressure in short-term US dollar funding markets. As a result, the tensions in the short-term segment of the euro zone money market abated considerably.

Following the bankruptcy of Lehman Brothers on 15 September 2008, the uncertainty about the financial health of major banks worldwide led to a virtual collapse in activity in many financial market segments. Banks built up large liquidity buffers, while shedding risks from their balance sheets and tightening loan conditions. Given the crucial importance of banks for the financing of the euro zone economy and in the ECB's monetary policy implementation, this situation was alarming in view of a high risk of a credit crunch and a high risk of the central bank's inability to steer monetary conditions. The ECB, like other major central banks, rapidly reduced its key interest rates to historically low levels, but a key element of its response to retain effectiveness in influencing monetary conditions consisted of its non-standard policy measures. The aim was to continue preserving price stability, contributing to stabilizing the financial situation, and limiting the fallout on the real economy. As regards interest rate policy, the ECB cut the main refinancing rate by 50 basis points on October 2008, in a concerted and historic move with other major central banks; it reduced its key interest rates further by a total of 325 basis points within a period of 7 months until May 2009. The main refinancing rate was brought to a historic low of $1 \%$, a level not seen in euro zone countries in decades.

At the same time, the ECB adopted a number of non-standard measures to support financing conditions and credit flows to the euro zone economy over and beyond what could be achieved through reductions in key interest rates alone (so-called 'enhanced credit support'). The nonstandard measures implemented from October 2008 onwards were tailored to the specific, bank-based financial structure of the euro zone, aiming at supporting bank liquidity and funding. They comprised five key elements, drawing in part on the experience with non-standard measures during the financial turmoil, which include:

- Fixed-rate full allotment. A fixed-rate full allotment tender procedure was adopted for all refinancing operations during the financial crisis. Thus, contrary to normal practice, eligible euro zone financial instituti-

ECB, (2010b), 'The ECB’s Monetary Policy Stance During the Financial Crisis', Monthly Bulletin, January 2010, 5.

Vol. 11, No 1, 2014: 41-52 
ons have unlimited access to central bank liquidity at the main refinancing rate, as always subject to adequate collateral.

- Extension of the maturity of liquidity provision. The maximum maturity of the longerterm refinancing operations (LTROs) was temporarily extended (subsequently to 12 months in June 2009). In combination with the first element, this contributed to keeping money market interest rates at low levels and increased the Eurosystem's intermediation role aimed at easing refinancing concerns of the euro zone banking sector, especially for term maturities. Reduced liquidity costs and uncertainty and a longer liquidity planning horizon were expected to encourage banks to continue providing credit to the economy.

- Extension of collateral eligibility. The list of eligible collateral accepted in Eurosystem refinancing operations was extended, in fact allowing banks to refinance a larger share of their balance sheet with the Eurosystem. The ability to refinance less liquid assets through the central bank provides an effective remedy to liquidity shortages caused by a sudden stop in interbank lending.

- Currency swap agreements. The Eurosystem temporarily provided liquidity in foreign currencies, at various maturities, and against euro-denominated collateral. For this, the ECB used reciprocal currency arrangements, notably with the US Federal Reserve. A massive shortfall in US dollar funding was thus avoided: euro zone banks and associated offbalance-sheet vehicles had significant liabilities in US dollars, having provided major financing to several US market segments, including real estate and subprime.

- Covered bond purchase programme (CBPP). The Eurosystem committed to purchasing covered bonds ${ }^{4}$ denominated in euro and issued in the euro zone for a total value of $€ 60$ billion gradually over the period between June 2009 and June 2010. The aim of the programme was to revive the covered bond market, which is a primary source of funding for banks in large parts of the euro zone. It is the largest and the most active segment of the fixed income market alongside the public sector bond market. Such covered bonds - known as 'Pfandbriefe' in Germany, 'obligations foncières' in France and 'cédulas' in Spain - are long-term debt securities that are issued by banks to refinance loans to the public and private sectors, often in connection with real estate transactions. These covered bonds - unlike mortgage-backed securities - have the specific legal characteristic of 'double protection': recourse to the issuer as well as additional security provided by the legal pledge of the assets financed. The size of the programme represented around $2.5 \%$ of the 
total outstanding amount of covered bonds, which in the given context was effective as a catalyst to restart activity in this market.

\subsection{The ECB's response to the euro zone sovereign debt crisis}

In early 2010 the euro zone sovereign debt crisis began with acute market expectations about a possible Greek sovereign default, with a risk of impact on Ireland, Portugal, and even Spain and Italy. In May 2010 some secondary markets for government bonds began to dry up completely; large-scale sale offers faced virtually no buy orders and yields reached levels that would have quickly become unsustainable for any sovereign. Given the crucial role of government bonds as benchmarks for private-sector lending rates and their importance for bank balance sheets and liquidity operations, this development was considered to impair the transmission of policy interest rate decisions to the real economy.

To help calm the market down and support a better functioning of the monetary policy transmission mechanism, the ECB established its Securities Markets Programme (SMP) to ensure depth and liquidity in those market segments that were dysfunctional. Under the SMP, Eurosystem interventions could be carried out in the euro zone public and private debt securities markets. In line with Treaty provisions, interventions in sovereign bond markets were strictly limited to secondary markets. In addition, they were also fully sterilized through liquidity absorbing operations, so as to not affect central bank liquidity conditions. In alleviating disruptions, the SMP was effective at the outset and led to some stabilization in markets as well as to an immediate and substantial decline of government bond yields. Its impact was re-enforced by the parallel announcement on the establishment of a European Financial Stability Facility through which governments could provide mutual financing support in adjustment programmes for specific countries.

SMP helped to avoid for some time an uncontrolled increase in sovereign bond yields and thereby in general financing costs for the economy with adverse implications for price stability. In addition, it helped to reduce contagion across countries and thereby shielded monetary policy transmission in large parts of the euro zone. Other non-standard measures also contributed to dampen the implications of impairments in the sovereign bond markets. The ECB mitigated the impact on bank funding through a renewed lengthening in the maturity of its liquidity provision and through changes in its collateral framework. As a result, government bonds amounted to less than $20 \%$ of the assets deposited as collateral in Eurosystem operations, compared to close to 30\% in 2006. The remaining $80 \%$ included covered bonds, asset-backed securities, or other financial instruments. 


\section{Conclusion}

The current economic crisis, which has entered its sixth year of existence, has triggered some new mechanism that should respond to the various economic problems. The combination of deflationary shocks and financial market turbulences has led the central banks to get more actively involved in addressing nonstandard, unconventional measures of monetary policy. The global recession forced monetary regulators to strictly abide by the policy of low interest rates. In addition to the reference interest rates, which should serve as the key parameter in the transmission mechanism, what also characterizes these measures are huge liquidity reserves channeled into the banking sector, purchase of long-term securities, and direct interventions in certain segments of the financial market.

This paper has reviewed the ECB's non-standard monetary policy measures during the global financial crisis and the euro zone sovereign debt crisis. Monetary policy clearly cannot directly address the underlying causes of the crisis and the associated need for deleveraging by financial and non-financial sectors or the need for rebalancing within the euro zone. This requires reforms and action on the part of governments and regulators, individually and collectively, with respect to fiscal consolidation, structural reforms, financial regulation and the European governance framework. At the same time, in financial crises central banks have an important role to play in providing liquidity, averting disorderly deleveraging and fire-sales of assets, and hence adverse self-fulfilling dynamics, as well as, more broadly, in safeguarding monetary policy transmission to ensure price stability .

The ECB's response to the crisis has, in particular, relied on banks as intermediaries to ensure the continuous financing of households and firms, rather than intervening in asset markets directly. The rationale of safeguarding monetary policy transmission across the euro zone and addressing dysfunctional market segments differs from that behind quantitative easing, which is aimed at providing extra monetary stimulus via outright transactions when the lower bound for policy rates has been reached. 


\section{Literature}

- Bank of England, Quantitative Easing Explained, Putting more money into our economy to boost spending, London, 2011, 7-11.

- Cour-Thimann Philippine, Winkler Bernhard, The ECB's non-standard monetary policy measures, ECB Working Paper No. 1528, April 2013, 10-26.

- ECB, (2010b), The ECB's Monetary Policy Stance During the Financial Crisis, Monthly Bulletin, January 2010, 5.

- ECB, Liquidity Analysis, http://www.ecb.europa.eu/mopo/liq/html/index. en.html (02.09.2013.)

- Elliot Larry, Guardian Business Glossary: Quantitative Easing, London, The Guardian, 2009. http://www.guardian.co.uk/business/2008/oct/14/businessglossary (01.09.2013.)

- Giannone Domenico, Lenza Michele, Pill Huw, Reichlin, Lucrezia, The ECB and the Interbank Market, Discussion Paper No. 8844, CEPR, 2012, 1-12.

- Lenza Michele, Pill Huw, Reichlin Lucrezia, Monetary Policy in Exceptional Times, Working paper No 1253, European Central Bank, 2010, 9-20.

- Peersman Gert, Macroeconomic Effects of Unconventional Monetary Policy in the Euro Area, Working Paper Series No. 1397, ECB, 2011, 4-25.

Paper received: January $9^{\text {th }}, 2014$

Approved for publication: January $19^{\text {th }}, 2014$
Rad primljen: 9. januar 2014. Odobren za štampu: 19. januar 2014. 